\title{
Amir Syamsuadi*
}

Universitas Abdurrab, Riau, Indonesia

\section{Zamhasari}

Universitas Abdurrab, Riau, Indonesia

\section{Seri Hartati}

Universitas Abdurrab, Riau, Indonesia

\section{Liza Trisnawati}

Universitas Abdurrab, Riau, Indonesia

\begin{abstract}
Abstrak
Artikel ini mengkaji strategi politik terbuka Partai Keadilan Sejahtera (PKS) dalam memenangkan persaingan pemilihan gubernur dan wakil gubernur di Provinsi Riau pada tahun 2018. PKS dan partai koalisinya saat itu mengusung pasangan Syamsuar-Edy Natar. PKS melakukan sejumlah strategi politik untuk memenangkan persaingan tersebut, yaitu mobilisasi massa, optimalisasi koalisi partai, pemberdayaan politik, dan strategi komunikasi politik. Artikel ini berargumen bahwa untuk memenangkan persaingan politik, PKS membangun pragmatisme politik dengan menggunakan strategi politik terbuka dalam sistem politik demokrasi di Indonesia. Karena itu, anggapan bahwa PKS menganut ideologi Islam politik yang tertutup dan hanya menunggangi sistem demokrasi adalah kurang tepat. Sebagai partai Islam terbesar di Indonesia, PKS berhasil membuktikan bahwa pragmatisme politik melalui strategi politik terbuka menjadi kunci penopang keberhasilannya dalam persaingan politik di Indonesia.
\end{abstract}

\section{Kata-kata Kunci}

PKS, pragmatisme, strategi politik terbuka, partai Islam, pemilihan gubernur

\footnotetext{
* Penulis untuk korespondensi: 


\section{Abstract}

This article describes the open political strategy, which was adopted by Partai Keadilan Sejahtera (PKS), an Islamic party, in its attempt to win the gubernatorial election in Riau province in 2018. PKS and its allied parties promoted Syamsuar-Edy Natar as their governor and vice governor candidates. PKS employed some political strategies to win the election including mass mobilization, optimization of party coalition, political empowerment, and political communication. This article argues that PKS adopted political pragmatism by conducting an open political strategy to win the Riau gubernatorial election. Therefore, it is inappropriate to label PKS as a party with closed Islamic ideology and takes advantage of a new democracy in Indonesia for its religiouspolitical interests. As the biggest Islamic party in Indonesia, PKS has shown that political pragmatism through open political strategy is an important key to the successful political winning in Indonesia.

\section{Key Words}

PKS, pragmatism, open political strategy, Islamic party, governatorial election

\section{Pendahuluan}

Salah satu partai Islam yang muncul pada 1998 di tengah euforia politik pasca tumbangnya pemerintahan Orde Baru yang otoriter adalah Partai Keadilan Sejahtera (PKS). Pada awalnya, PKS yang berasal dari "gerakan Tarbiyah" didirikan untuk meraup suara pemilih Muslim muda perkotaan (Hasan 2012; Fuad 2017). Namun, belakangan PKS secara pragmatis memperlebar ceruk pasar pemilihnya dengan menjadi partai terbuka (Hilmy 2010:123). Sebagai partai terbuka terutama pasca Mukernas di Bali, 1-3 Februari 2008, PKS sekarang tidak lagi membatasi ceruk pemilihnya di kalangan Muslim, tetapi juga kaum nasionalis termasuk kelompok non-Muslim (Muhtadi 2012:224). Meskipun terdapat pertentangan antara "faksi keadilan" dan "faksi kesejahteraan" di internal PKS sendiri, dorongan kuat atas posisinya sebagai partai terbuka membuat PKS menjadi salah satu partai papan menengah yang semakin diperhitungkan (Permata 2013).

Karena itu, isu PKS sebagai partai Islam yang mencita-citakan sebuah sistem teokrasi yang tertutup dan anti demokrasi semakin hilang dalam perbincangan. Hal ini salah satunya terlihat dalam praktik keterlibatan PKS dalam Pemilihan Umum (Pemilu) yang secara konsisten diikuti dan banyak mendulang sukses bagi keberlangsungan partai ini di berbagai daerah di Indonesia (Permata 2008). Ini dapat dilihat dalam praktik pemilihan gubernur dan wakil gubernur di Provinsi Riau pada tahun 2018 yang dimenangkan oleh koalisi partai PKS, Partai Amanat Nasional (PAN) dan Partai Nasional Demokrat (Nasdem) yang mendukung pasangan Syamsuar-Edy Natar Nasution. 
Berangkat dari fenomena di atas, artikel ini mengkaji strategi politik PKS dalam memenangkan persaingan pemilihan gubernur dan wakil gubernur di Riau pada tahun 2018. Artikel ini berargumen bahwa PKS membangung pragmatisme politik untuk memenangkan persaingan politik dengan menggunakan strategi politik terbuka sebagai prasyarat penting dalam sistem politik demokrasi di Indonesia. Karena itu, kuranglah tepat anggapan bahwa PKS yang menganut ideologi Islam politik yang tertutup dan hanya menunggangi sistem demokrasi. Sebagai partai Islam terbesar di Indonesia, PKS berhasil membuktikan bahwa pragmatisme politik melalui strategi politik terbuka menjadi kunci penopang keberhasilannya dalam persaingan politik di Indonesia (Hidayat 2012).

Kajian tentang strategi politik terbuka PKS pada pemilihan gubernur dan wakil gubernur Riau tahun 2018 ini penting dilakukan untuk menunjukkan bahwa kesuksesan partai Islam tidak lagi hanya ditentukan oleh dukungan basis massa politik Islamis, tetapi juga pragmatisme dalam membangun keterbukaan politik terhadap pemilih dalam sistem demokrasi. Riau sebagai provinsi yang menjadi salah satu basis politik PKS di Indonesia, selain Jakarta dan Jawa Barat, menunjukkan kesuksesan strategi politik partai Islam yang melakukan strategi terbuka melalui dukungan pasangan calon yang berpengalaman dan terbuka, serta terbangunnya koalisi partai dengan beberapa partai nasionalis.

Sudah banyak sekali kajian tentang meroketnya keberhasilan PKS sebagai partai baru di era pasca reformasi. Umumnya, studi kesarjanaan tentang PKS lebih banyak menyoroti partai ini dari sisi kesuksesannya di level nasional, baik yang memandangnya secara positif maupun kritis negatif. Sebagian sarjana menganalisis posisi PKS dilihat dari isu perkembangan ideologi Islamisme dan demokrasi di Indonesia (Rahmat 2008), perbandingan dengan partai Islam di Turki dan Malaysia (Nurdin 2009; Hidayat 2012), dan pengaruh Ikhwanul Muslimin Mesir terhadap gerakan Tarbiyah dan PKS (Nurdin 2019; Damanik 2002; Machmudi 2006). Belakangan, terdapat juga kajian tentang kesuksesan PKS dilihat dari sisi gerakan sosial melalui kesempatan politik, mobilisasi sumber daya dan pembingkaian ideologi gerakan (Muhtadi 2012).

Namun, kajian-kajian di atas menunjukkan bahwa tidak banyak kajian yang memfokuskan analisisnya pada strategi politik terbuka PKS dalam konteks pemilihan umum kepala daerah. Karena itu, untuk mengisi kekosong literatur ini, artikel ini mengkaji PKS dengan fokus kajian pada strategi politik terbuka PKS di tingkat lokal sebagai bagian dari pragmatisme politik dalam memenangkan persaingan melalui aturan main yang ditetapkan dalam sistem demokrasi.

\section{Strategi Politik Terbuka PKS}

Sebagai pilar demokrasi, peran partai politik dalam sistem perpolitikan nasional merupakan wadah seleksi kepemimpinan nasional dan daerah (Syamsuadi \& Yahya 2018). Bila manajemen partai politik berjalan dengan baik, maka posisi partai politik tersebut dapat berkiprah di pentas politik secara baik dan pada 
gilirannya dapat berkontribusi terhadap kualitas bangunan demokrasi. Sebaliknya, bila manajemen partai politik tidak berlangsung dengan baik, maka kiprahnya sebagai partai politik akan menjadi buruk pula. Bahkan lebih dari itu, partai politik dengan manajemen yang buruk dapat memberikan dampak buruk bagi bangunan demokrasi (Sahid \& Nurjaman 2017).

Salah satu upaya manajemen partai politik yang umum dilakukan oleh partai politik di Indonesia adalah keterbukaan dalam strategi politik. Hal ini salah satunya dapat dilihat dalam kasus PKS. Partai ini awalnya merupakan gerakan dakwah Tarbiyah di berbagai kampus terkemuka di Indonesia. Karena itu, sejak didirikan tahun 1998, PKS mendeklarasikan diri sebagai partai dakwah yang berusaha maraup suara pemilih dari kalangan Muslim muda perkotaan. Tetapi, sejak Mukernas Bali 2008, PKS kemudian mengalami pergeseran dengan membuat strategi politik melalui pelebaran ceruk pemilihnya, salah satunya dengan merekrut calon anggota legislatif dari non-Muslim. Hal ini menandai perubahan penting dalam tubuh PKS yang berakibat pada munculnya faksi di kalangan internasl partai tersebut.

Kebijakan PKS menjadi partai terbuka tersebut secara politis tidak hanya terkait dengan pragmatisme politik, tetapi juga dinamika politik internal partai. Dari perspektif pragmatisme politik, pilihan PKS mengubah baju partainya dari partai dengan kesan "ekslusif" menjadi partai yang terbuka tidak lepas dari targettarget politik praktis PKS terutama terkait perolehan suara pada Pemilu, baik Pemilu Presiden dan Wakil Presiden maupun Pemilu Legislatif (DPR dan DPRD). Maka, tidak mengherankan jika pergeseran ke arah partai terbuka menjadi salah satu strategi politiknya yang utama. Perubahan strategi politik PKS menjadi sebuah partai terbuka dapat menjadi "propaganda" ampuh sehingga bisa diterima oleh masyarakat Indonesia secara lebih luas tanpa tersekat oleh batas-batas primordial suku, agama, ras dan antar golongan (Wijaya 2014).

Dilihat dari perspektif dinamika politik internal partai, perubahan PKS menjadi partai terbuka menunjukkan kemenangan salah satu faksi dalam internal PKS sendiri. Para pengamat politik menyebutnya dengan istilah "Faksi Kesejahteraan", "Faksi Pragmatis-Realistis" atau "Faksi Moderat" yang lebih menghendaki agar PKS menjadi partai lebih "longgar", realistis dengan peta kondisi di lapangan, dan agresif dalam menarik dukungan di luar basis masa Islam dengan terobosan-terobosan yang lebih berani. Hal ini berseberangan dengan faksi lain yang dikenal dengan istilah "Faksi Keadilan", "Faksi Idealis-Ideologis" atau "Faksi Fundamentalis" yang lebih menghendaki PKS tetap di jalur awal sebagai partai "kanan" atau setia pada PKS "lama" dengan nilai-nilai Islam yang kental dan konservatif.

Sebagai sebuah partai politik, perubahan kebijakan PKS menjadi partai terbuka merupakan bagian dari strategi komunikasi politik partai yang muaranya berujung pada upaya untuk mendapatkan dukungan luas dari masyarakat dalam rangka untuk memperkuat posisinya dalam pusaran kekuasaan politik di Indonesia. PKS mencoba mempromosikan diri agar posisinya lebih bisa diterima masyarakat 
melalui strategi politik sebagai partai terbuka bagi semua elemen anak bangsa. Dilihat dari sudut pandang komunikasi politik lebih jauh, kebijakan PKS menjadi partai terbuka adalah bagian dari propaganda partai (Wijaya 2014).

Dalam konteks ini, PKS mencoba menggunakan ide-ide umum yang berlaku di masyarakat luas sebagai pesan politiknya agar eksistensinya, baik sebagai sebuah komprador politik maupun sebagai sebuah komunitas Islam, lebih bisa diterima oleh masyarakat Indonesia secara luas. Ide-ide umum yang dimaksud adalah fakta sosiologis kemajemukan bangsa Indonesia yang terwadahi melalui representasi pilar-pilar kebangsaan dan kenegaraan, yaitu Pancasila, UUD 1945, Negara Kesatuan Republik Indonesia (NKRI) dan Bhinneka Tunggal Ika sebagai pilar-pilar kebangunan bangsa Indonesia.

Hal lainnya adalah pengasosiasian ide-ide umum bahwa PKS merupakan bagian dari Islam moderat mengingat mayoritas Muslim Indonesia memiliki pemahaman Islam yang moderat (pertengahan). Islam moderat sendiri dipandang sebagai model penafsiran secara teologis atas ajaran Islam yang dinilai lebih sesuai, lebih terbuka dan lebih bisa menerima fakta pluralitas termasuk kemajemukan bangsa Indonesia. Karenanya, pilihan PKS menjadi partai terbuka adalah pilihan yang rasional mengingat partai terbuka dianggap sebagai wadah terbaik yang dapat menampung pluralitas bangsa Indonesia melalui representasi pilar-pilar kebangsaan dan kenegaraan maupun asosiasinya sebagai bagian Muslim moderat.

Karena itu, melalui penggunaan teknik propaganda ini, diharapkan PKS bisa lebih hadir dan diterima oleh semua komponen anak bangsa, meskipun secara ideologis, PKS secara tegas tetap menganut ideologi Islam. Berdasarkan pandangan pragmatisme politik tersebut, PKS mencoba melakukan sebuah akrobat politik melalui praksis "keterbukaan" sebagai kebijakan baru partai. Strategi politik ini merupakan bentuk komunikasi politik partai dalam upaya agar masyarakat Indonesia, baik secara struktural maupun kultural, lebih dapat menerima PKS. Hal ini terlihat dalam perolehan suara PKS dalam Pemilu yang pernah diikutinya hingga saat ini (Tabel 1).

Tabel 1

Suara PKS pada Pemilu Nasional Tahun 1999-2019

\begin{tabular}{ccccc}
\hline Pemilu & $\begin{array}{c}\text { Nomor } \\
\text { Urut }\end{array}$ & $\begin{array}{c}\text { Jumlah } \\
\text { Suara }\end{array}$ & Presentase & $\begin{array}{c}\text { Jumlah Kursi } \\
\text { di DPR RI }\end{array}$ \\
\hline Tahun 1999 & 24 & 1.436 .565 & $1,35 \%$ & 7 \\
\hline Tahun 2004 & 16 & 8.325 .020 & $7,34 \%$ & 45 \\
\hline Tahun 2009 & 8 & 8.206 .955 & $7,88 \%$ & 59 \\
\hline Tahun 2014 & 3 & 8.480 .204 & $6,79 \%$ & 40 \\
\hline Tahun 2019 & 8 & 11.493 .663 & $8,21 \%$ & 50 \\
\hline \multicolumn{5}{c}{ Sumber: Diolah dari berbagai sumber, 2020 }
\end{tabular}


Dalam pengalaman Pemilu 1999-2019 tersebut, PKS kemudian sepertinya mengambil kesimpulan bahwa menjadi sebuah partai terbuka bagi semua golongan adalah pilihan tepat untuk meraih dukungan suara semaksimal mungkin dari pemilih (Wijaya 2014). Hal ini terbukti tatkala PKS yang pada Pemilu 1999 bernama Partai Keadilan (PK) hanya memperoleh 1,6\% atau 1,4 juta suara nasional. Hal ini tidak lepas dari penggunaan simbol-simbol kelompok maupun pesan-pesan komunikasi politiknya yang relatif terkesan "eksklusif" di mata umumnya masyarakat Indonesia. Tetapi, hal tersebut kemudian berubah drastis pada Pemilu 2004, di mana peraihan suara PKS (metamorfosis PK) melonjak menjadi $7,3 \%$ atau 8,3 juta suara nasional, lalu meningkat pada Pemilu 2009 yang meraih 7,8\% atau 8,2 juta suara nasional, 6,79\% pada Pemilu tahun 2014 dan 11.4 juta suara pada Pemilu 2019.

Walaupun ada sedikit penurunan suara di tahun 2014, konsistensi dan tingkat dukungan PKS terus mengalami peningkatan. Hal ini tidak terlepas dari pesan komunikasi politik PKS yang didesain tampil lebih "terbuka" dengan tidak mengusung lagi pesan-pesan politik yang dinilai terlalu sempit seperti tema-tema bernuansa agama (Islam), melainkan pesan-pesan politik bersifat umum yang relatif terbuka bagi masyarakat luas.

Keterbukaan strategi politik PKS di level nasional tersebut juga kemudian tersebar secara merata dalam praktik politik di level daerah. Salah satu provinsi yang menunjukkan kesuksesan strategi politik terbuka adalah Riau, sebuah provinsi yang menjadi salah satu basis politik PKS di luar Jawa yang menjadi tempat pendulang suara terbanyak bagi PKS dalam Pemilu nasional dan pemilihan kepala daerah.

\section{PKS dan Konstelasi Politik di Provinsi Riau}

Berdasarkan agama yang dianut, mayoritas penduduk di Provinsi Riau memeluk Agama Islam, yaitu sebesar 5.312.814 jiwa (87,47\%). Selain Muslim, provinsi ini juga dihuni oleh penduduk non-Muslim yang terdiri dari Kristen sebanyak 562.907 jiwa (9,27\%), Buddha sebanyak 132.593 jiwa (2.18\%), Katolik 61.391 jiwa (1.01\%), Kong $\mathrm{Hu} \mathrm{Cu} 2.130$ jiwa (0.04\%), Hindu 757 jiwa (0.01\%), dan kepercayaan lainnya sebanyak $1.508(0.02 \%)$ (http//:www.riau.go.id, 2018). Sebagai provinsi yang mayoritas penduduknya beragama Islam, Provinsi Riau tentu saja memberikan ruang cukup besar kepada partai berideologi Islam seperti PKS. Hal ini dibuktikan dengan semakin meningkatnya keterpilihan para legislator di DPRD Riau yang berasal dari PKS dari Pemilu 2004 sampai Pemilu 2019 (Tabel 2). 
Tabel 2

Daftar Perolehan Suara PKS dan Kursi DPRD Provinsi Riau

Tahun $2004-2019$

\begin{tabular}{ccc}
\hline Pemilu & Jumlah Suara & $\begin{array}{c}\text { Jumlah Kursi di DPRD } \\
\text { Provinsi Riau }\end{array}$ \\
\hline Tahun 2004 & 55.765 & 5 \\
\hline Tahun 2009 & 45.616 & 4 \\
\hline Tahun 2014 & 27.787 & 3 \\
\hline Tahun 2019 & 69.833 & 7 \\
\hline
\end{tabular}

Sumber: data diolah dari berbagi sumber, 2020

Tidak hanya mengisi pos-pos legislator, semenjak PKS ini bermetamorfosis dari Partai Keadilan (PK) pada tahun 2003, partai ini sudah menelurkan dan memenangkan beberapa pemilihan calon kepala daerah di Indonesia. Hal ini membuktikan bahwa mesin politik PKS bekerja dengan cukup sempurna. Jika berangkat dari peta dukungan PKS pada pelaksanaan Pilkada Serentak I tahun 2015 di kabupaten/kota yang ada di Provinsi Riau, maka PKS terlihat sangat mendominasi kemenangan calon yang didukungnya. Tabel 3 di bawah menunjukkan kesuksesan PKS dalam mendukung pasangan calon bupati dan walikota di Provinsi Riau tahun 2015 dan 2017.

Tabel 3

Dukungan PKS pada Pilkada Serentak 2015 dan 2017 di Provinsi Riau

\begin{tabular}{clcc}
\hline No & Kabupaten/Kota & Pasangan Calon & Status \\
\hline 1 & Bengkalis & Amril Mukminin-Muhammad & Menang \\
\hline 2 & Pelalawan & M Harris-Zardewan & Menang \\
\hline 3 & Siak & Syamsuar-Alfedri & Menang \\
\hline 4 & Kuantan Sengingi & - & - \\
\hline 5 & Rokan Hilir & Herman Sani -Taem & Kalah \\
\hline 6 & Rokan Hulu & Hafith Syukri-Nasrul Hadi & Kalah \\
\hline 7 & Kep. Meranti & Irwan-Said Hasyim & Menang \\
\hline 8 & Indragiri Hulu & Yopie-Khairizal & Menang \\
\hline 9 & Dumai & Ikhsan-Yanti Komala & Kalah \\
\hline 10 & Pekanbaru & Firdaus-Ayat Cahyadi & Menang \\
\hline 11 & Kampar & Azis Zainal-Catur Sugeng & Menang \\
\hline & &
\end{tabular}


Dari 11 Pilkada serentak di seluruh kabupaten/kota di Provinsi Riau gelombang I dan II tersebut, PKS terlihat mendominasi kemenangan pasangan calon yang diusungnya, yakni sebanyak tujuh pasangan calon. Hal ini membuktikan bahwa PKS merupakan partai yang memiliki strategi politik yang matang dalam memenangkan pasangan calon yang diusung dalam pelaksanaan pemilihan kepala daerah. Hal yang sama terlihat pada kesuksesan PKS dalam perhelatan pelaksanaan Pemilihan Kepala daerah Gubernur dan Wakil Gubernur Riau Tahun 2018 sebagaimana akan dijelaskan. PKS berhasil meraih kemenangan dalam mendukung pasangan Syamsuar dan Edy Natar Nasution sebagai pasangan gubernur dan wakil gubernur.

\section{Pemilihan Gubernur dan Wakil Gubernur Riau Tahun 2018}

Bagian ini akan menjelaskan tentang proses pemilihan gubernur dan wakil gubernur Riau tahun 2018. Penjelasan ini penting untuk meletakkan PKS dalam proses kontestasi politik tersebut. Penjelasan akan difokuskan pada koalisi PKS dan partai-partai lain, calon yang diusung dan hasil pemilihan yang menunjukkan angka keberhasilan PKS dalam mengusung calon gubernur dan wakil gubernur di Riau.

Pada pelaksanaan pemilihan Gubernur dan Wakil gubernur di Provinsi Riau tahun 2018, terdapat beberapa pasangan calon yang mengikuti kontestasi politik tersebut (Tabel 4). Pertama, pasangan Arsyadjuliandi Rachman dan Suyatno. Pasangan ini diusung oleh partai Golongan Karya, Partai Demokrasi Indonesia Perjuangan, dan Partai Hati Nurani Rakyat. Arsyadjuliandi Rachman merupakan Ketua DPD Partai Golkar Provinsi Riau dan Suyatno merupakan Ketua DPD PDIP Provinsi Riau sehingga wajar saja apabila pasangan ini memperoleh dukungan dari partai pengusung.

Kedua, pasangan Firdaus dan Rusli Efendi yang diusung oleh partai Demokrat dan Partai Persatuan Pembangunan. Firdaus merupakan kader internal Demokrat yang juga merupakan Walikota Pekanbaru dan Rusli Efendi merupakan Ketua DPD PPP Provinsi Riau sehingga dengan kekuatan politik itu wajar saja ketika mereka memperoleh dukungan tersebut.

Ketiga, pasangan Lukman Edi dan Hardianto. Pasangan ini diusung oleh Partai Kebangkitan Bangsa dan Partai Gerakan Indonesia Raya (Romadan 2019). Lukman Edi merupakan kader internal Partai Kebangkitan Bangsa. Dia adalah anggota legislatif RI perwakilan Partai Kebangkitan Bangsa yang memiliki pengaruh besar di internal Partai Kebangktian Bangsa.

Keempat, pasangan Syamsuar dan Edy Natar Nasution. Pasangan ini merupakan pasangan Calon Gubernur Riau dan Calon Wakil Gubernur Riau yang berasal dari kader eksternal partai dan kader non-partai pengusung pada pemilihan kepala daerah di Provinsi Riau. Pada proses kandidasi di partai politik, pasangan Syamsuar dan Edy Afrizal Natar Nasution memperoleh dukungan dari Partai Amanat Nasional, PKS, dan Partai Nasional Demokrat. 
PKS mendukung pasangan ini didasarkan pada pengalaman Syamsuar yang pernah menjadi Bupati Siak selama dua periode dan Edy Natar Nasution yang merupakan seorang brigadir jenderal TNI sehingga diharapkan bisa memperluas dukungan pemilih. Pengalaman PKS dalam mendukung Syamsuar tersebut menjadi belanjut untuk juga memberi dukungan dalam pemilihan gubernur dan wakil gubernur Riau tahun 2018. Kombinasi antara politisi berpengalaman dan seorang brigjen TNI menunjukkan pragmatisme PKS dalam membangun strategi politik terbuka sehingga bisa dipahami koalisi yang terbentuk dalam pemilihan gubernur dan wakil gubernur tersebut, PKS bergabung dengan PAN dan Partai Nasdem yang memiliki visi politik nasionalis dibanding partai-partai Islam dan calon gubernur dan wakil gubernur yang menonjolkan latar belakang keislaman.

Tabel 4

Pasangan Calon Gubernur dan Wakil Gubernur Riau Tahun 2018

\begin{tabular}{ccc}
\hline $\begin{array}{c}\text { Nomor } \\
\text { Urut }\end{array}$ & Nama Pasangan Calon & Parpol Pengusung \\
\hline I & $\begin{array}{c}\text { Syamsuar-Edy Natar } \\
\text { Nasution }\end{array}$ & PKS, PAN, Nasdem \\
\hline II & $\begin{array}{c}\text { Asrayadjuliandi Rach- } \\
\text { man-Suyatno }\end{array}$ & $\begin{array}{c}\text { Golkar, Hanura, } \\
\text { PDIP }\end{array}$ \\
\hline III & Firdaus dan Rusli Effendi & Demokrat dan PPP \\
\hline IV & $\begin{array}{c}\text { Muhammad Lukman Edy } \\
\text { dan Hardianto } \\
\text { Sumber: KPU Riau, 2018 }\end{array}$ & Gerindra dan PKB
\end{tabular}

Pilkada tidak hanya sekedar berhasil melahirkan pemimpin daerah baru dengan terpilihnya pasangan gubernur dan wakil gubernur. Tetapi, lebih dari itu, bagaimana prosesi Pilkada dapat menghasilkan pemimpin terpilih yang benarbenar sesuai dengan harapan masyarakat. Pilkada sebagai ajang kontestasi politikelektoral dapat melahirkan pemimpin baru yang mampu menawarkan perubahan ke arah yang lebih baik. Untuk merealisasikan harapan ideal ini, KPU Provinsi Riau sebagai penyelenggara Pemilu menetapkan beberapa tahapan pelaksanaan pemilihan gubernur dan wakil gubernur Riau (Tabel 5). 


\section{Tabel 5}

Jadwal Tahapan Pelaksanaan Pemilihan Gubernur dan Wakil Gubernur Riau 2018

\begin{tabular}{ll}
\hline \multicolumn{1}{c}{ Periode Tanggal } & \multicolumn{1}{c}{ Susunan Kegiatan } \\
\hline Juni 2017 & $\begin{array}{l}\text { Tahapan Pilkada sudah dimulai dengan kegiatan } \\
\text { sosialisasi, }\end{array}$ \\
\hline September 2017 & $\begin{array}{l}\text { Penandatangan nota Naskah Perjanjian Hibah } \\
\text { Daerah (NPHD) }\end{array}$ \\
\hline Oktober-November 2017 & Pembentukan PPK dan PPS \\
\hline Oktober 2017-Juni 2018 & Pendaftaran Pemantau \\
\hline 22 November-26 & Penyerahan Dukungan Perseorangan \\
November 2017 & Pendaftaran Pasangan Calon \\
\hline 8-10 Januari 2018 & Penetapan Calon \\
\hline 12 Februari 2018 & Masa Kampanye \\
\hline 1 Maret- 20 Juni: & Hari Pencoblosan \\
\hline 27 Juni 2018 & Sumber: KPU Riau, 2018
\end{tabular}

Setelah dilakukan pendataan, jumlah daftar pemilih tetap pada pelaksanaan pemilihan gubernur dan wakil gubernur Riau tahun 2018 sejumlah 3.622.488 pemilih laki-laki dan perempuan. KPU Riau membagi zona kampanye menjadi empat zona, yaitu Zona I (Kota Pekanbaru, Kabupaten Kampar, dan Kabupaten Rokan Hulu), Zona II (Kabupaten Rokan Hilir, Kota Dumai dan Kabupaten Bengkalis), Zona III (Kabupaten Siak, Kabupaten Pelalawan, dan Kabupaten Meranti) dan Zona IV (Kabupaten Indragiri Hilir, Kabupaten Indragiri Hulu, dan Kabupaten Kuansing).

Setelah dilaksanakan pemilihan gubernur dan wakil gubernur Riau tahun 2018, berdasarkan hasil perhitungan pleno KPU Riau, pasangan nomor urut 1 Syamsuar-Edy Natar Nasution meraih suara terbanyak, yakni 799.289 suara (38,2 persen). Posisi kedua diraih oleh pasangan calon nomor urut 4 Arsyadjuliandi Rachman-Suyatno dengan 507.187 suara (24,2 persen). Posisi ketiga dimenangkan oleh pasangan calon nomor urut 3 Firdaus-Rusli Effendi dengan 416.248 suara (19,9 persen). Terakhir, pasangan calon nomor 2 Lukman Edy-Hardianto dengan 369.802 suara (17,7 persen) meraih posisi keempat.

Hasil rekapitulasi suara dari 12 kabupaten dan kota di Provinsi Riau menunjukkan Pilkada Riau akhirnya dimenangkan oleh pasangan nomor urut 1 Syamsuar-Edy Natar dengan meraih 799.289 suara. Pasangan yang diusung Partai PAN, PKS, dan Nasdem ini unggul di 9 kabupaten dan kota: di Kota Pekanbaru meraih 138.664 suara, di Kabupaten Rokan Hulu 69.946 suara, di Kabupaten 
Rokan Hilir 97.239 suara, di Kota Dumai 41.144 suara, di Kabupaten Bengkalis 87.709 suara, di Kabupaten Kepulauan Meranti 38.999 suara, di Kabupaten Siak 110.020 suara, di Kabupaten Pelalawan 36.161 suara, dan di Kabupaten Kuantan Singingi 39.881 suara.

Pasangan calon nomor urut 2 Lukman Edy-Hartdianto yang diusung Partai PKB dan Gerindra mendapat 369.802 suara. Pasangan calon nomor urut 3 FirdausRusli yang diusung Partai Demokrat dan PPP meraih 416.248 suara. Terakhir, pasangan calon nomor urut 4 Arsyadjuliandi Rachman-Suyatno yang diusung Partai Golkar, PDIP dan Hanura meraih 507.187 suara (KPU 2018).

\section{Strategi Politik Terbuka PKS dalam Pemilihan Gubernur dan Wakil Gubernur Riau Tahun 2018}

PKS merupakan partai politik yang memiliki pengelolaan yang baik dan rapi berkat manajemen yang baik dan kontribusi dari kader-kadernya. Sebagai partai dakwah, PKS didasarkan pada asas Islam (Hassan et al. 1998). Tetapi, dalam praktiknya, untuk meraih dukungan suara pemilih dan memenangkan persaingan dalam pemilihan gubernur dan wakil gubernur Riau tahun 2018, PKS melakukan strategi politik terbuka. Hal ini dilakukan dengan mengusung calon gubernur dan wakil gubernur yang dinilainya tidak saja mewakili mayoritas umat Islam, tetapi juga memiliki elektabilitas baik di masyarakat. Pasangan Syamsuar-Edy Natar Nasution memiliki kelebihan tidak hanya pada posisi popularitas Syamsuar yang sudah berpengalaman dalam politik di Riau, tetapi juga Edy Natar Nasution yang berlatar sebagai brigadir jenderal TNI yang dianggap memiliki ketegasan dan keterbukaan dalam menegakkan NKRI. Atas dasar inilah kemudian PKS melakukan koalisi dengan beberapa partai nasionalis seperti PAN dan Nasdem.

Strategi politik terbuka PKS pada pelaksanaan Pemilihan Gubernur dan Wakil Gubernur Provinsi Riau Tahun 2018 tersebut dapat dilihat pada taktik-taktik berikut: mobilisasi massa, optimalisasi koalisi, pengembangan dan pemberdayaan politik, dan komunikasi politik.

\section{Mobilisasi Massa}

Mobilisasi massa politik didefinisikan sebagai usaha aktor untuk mempengaruhi distribusi kekuasaan, yaitu suatu variabel direksional yang diperkenalkan dalam rangka menggambarkan dengan tepat jenis hubungan yang berkembang antara calon dan konstituen. Aktivitas mobilisasi terdiri dari tiga proses: proses kepentingan (dimensi kognitif), proses pembentukan komunitas (dimensi afektif) dan proses pemanfaatan instrumen (dimensi instrumental) (Tawakkal 2009).

Untuk memperkuat taktik mobilisasi massa, PKS yang tergabung dalam koalisi partai pengusung pasangan Syamsuar dan Edy Natar Nasution melakukan penguatan fungsi kelembagaan internal partai terlebih dahulu. Hal tersebut dapat dilihat menjelang pemilihan gubernur dan wakil gubernur Riau digulirkan. PKS 
melakukan rotasi posisi jabatan sekretaris DPW PKS Riau yang sebelumnya dijabat oleh Imam Zamroni digantikan oleh Junaidi Abdurrahman.

Penunjukan Junaidi Abdurrahman merupakan putusan dari Dewan Pimpinan Pusat (DPP) PKS. Sebelum menjabat Sekretaris Dewan Pimpinan Wilayah (DPW), Junaidi Abdurrahman dipercaya untuk menjabat Ketua Bidang Kesra DPW PKS Riau. Junaidi Abdurrahman bersama partai koalisi PKS, yaitu PAN dan Nasdem, aktif mensosialisasikan pasangan yang diusungnya dengan menyasar seluruh kabupaten/kota di Provinsi Riau. Kemudian, langkah mobilisasi bersama partai koalisi juga dilakukan dengan pembentukan komunitas menggunakan jargon yang menarik. Komunitas tersebut dimotori oleh sayap partai pengusung pasangan Syamsuar-Edy Natar Nasution yang tersebar di wilayah Riau daratan dan Riau pesisir. Citra yang ingin dibangun PKS dan partai koalisinya pada waktu itu adalah bahwa Syamsuar dan Edy Natar Nasution adalah figur representatif yang mampu memahami persoalan pembangunan, baik di wilayah pesisir maupun daratan. Soliditas partai dalam proses mobilisasi tergambar dari berbagai agenda kampanye yang disusun dengan partai koalisi di berbagai daerah.

Untuk menarik konstituen, isu yang diusungnya juga membawa unsur keislaman agar menjangkau berbagai kalangan termasuk pemilih pemula. PKS mendatangkan artis religi nasional yang juga dapat diterima oleh koalisi partai pengusung dengan mengundang artis-artis religi ibu kota pada saat kampanye seperti Opick dan Wali Band (detik.com 2018). Hal ini kemudian berpengaruh terhadap peningkatan dukungan pasangan calon yang diusung PKS. Citra yang ingin dibangun adalah bahwa pasangan yang didukung PKS ini tidak anti kesenian atau musik dengan tetap menjunjung tinggi nilai-nilai religiusitas. PKS berusaha meraih dukungan pemilih yang menentukan pilihan berdasarkan aspek religiusitas figur. Hal ini menjadi daya magnet bagi massa untuk kemudian mendukung dan memilihnya. Selain itu, untuk menarik dukungan massa pemilih, PKS bersama koalisinya juga menggelar acara tabligh akbar dengan mengundang para ustadz kondang asal Riau yang sudah populer di tingkat nasional dan internasional, yakni Ustadz Abdul Somad (UAS). Inilah yang menjadi salah satu strategi politik yang digunakan PKS dan koalisinya dalam upaya melakukan mobilisasi massa pemilih.

Secara politik, mobilisasi massa dimaksudkan untuk mengurangi ketegangan sosial yang dimunculkan oleh kelompok yang dikerahkan, untuk mengelaborasi program dalam rangka memperoleh suara bagi kandidat dan untuk membangun suatu struktur kelompok yang dapat dijadikan referensi bagi kandidat (Tawakkal 2009). Hal ini ditempuh dalam upaya memastikan posisi yang lebih baik dalam mobilisasi politik. Sebuah upaya yang ditujukan pada usaha-usaha kandidat untuk menggerakkan pemilih agar melakukan tindakan politik berupa peraihan dukungan pemilih. 


\section{Optimalisasi Koalisi Partai}

Koalisi partai politik memiliki tugas dan fungsi sebagai kendaraan politik dalam memfasilitasi kadernya untuk meraih dukungan lebih banyak. Koalisi partai mengharapkan adanya calon pemimpin yang dapat diterima semua kalangan, bersih dan berintegritas. Sehingga terbebas dari citra buruk sebagaimana dialami oleh gubernur sebelumnya yang tersangkut masalah hukum.

Pada proses penjajakan awal, bakal calon gubernur dan wakil gubernur, Syamsuar dan Edy Natar Nasution, yang didukung PKS melakukan lobi ke beberapa partai politik seperti DPW Partai Nasional Demokrat Riau, DPW Partai Amanat Nasional Riau, DPW Partai Keadilan Sejahtera Riau, DPD Partai Demokrat Riau, dam DPD Partai Hati Nurani Rakyat Riau (Romadan 2019). Hal ini dilakukan untuk mendapatkan dukungan partai politik lain yang memiliki visi dan misi yang sama dalam memenangkan persaingan politik.

Selain Syamsuar dan Edy Natar Nasution, sebetulnya terdapat beberapa bakal calon kandidat gubernur dan wakil gubernur Riau lainnya yang juga mendaftarkan diri ke PKS Riau. DPW PKS melakukan proses penjaringan kandidat dengan model silaturahmi (Romadan 2019). Beberapa kandidat merupakan figur potensial yang memiliki kekuatan politik pada pencalonan gubernur dan wakil gubernur Riau. Ada yang merupakan kepala daerah, kader internal PKS dan partai koalisi, hingga tokoh masyarakat Riau. Terdapat nama Irwan Nasir (ketua DPW PAN Riau), Syamsurizal (kader fungsioner DPW PAN Riau) dan Hendri Munief (Ketua DPW PKS Riau) yang mendaftarkan diri ke DPW PKS Riau untuk maju sebagai bakal calon gubernur dan bakal calon wakil gubernur Riau.

Menurut UU No. 10 Tahun 2016, proses pendaftaran calon disebutkan pada pasal 40 dan 40 A pada ayat (1), (2), (3), (4) dan (5). Dalam UU tersebut dinyatakan bahwa partai politik atau gabungan partai politik dapat mendaftarkan pasangan calon jika telah memenuhi persyaratan perolehan paling sedikit $20 \%$ (dua puluh persen) dari jumlah kursi DPRD atau 25\% dari akumulasi perolehan suara sah dalam pemilihan umum anggota DPRD di daerah yang bersangkutan. Partai Politik atau gabungan Partai Politik dalam mengusulkan pasangan calon menggunakan ketentuan memperoleh paling sedikit $20 \%$ dari jumlah kursi DPRD sebagaimana dimaksud pada ayat (1). Jika hasil bagi jumlah kursi DPRD menghasilkan angka pecahan, maka perolehan dari jumlah kursi dihitung dengan pembulatan ke atas.

Sebagai pilar demokrasi, peran partai politik dalam sistem perpolitikan nasional merupakan wadah seleksi kepemimpinan nasional dan daerah (Syamsuadi dan Yahya 2018). Kemenangan pasangan yang diusung oleh koalisi partai politik menurut UU No. 10 Tahun 2016 ini juga tidak lepas dari strategi partai politik dalam melihat kesempatan atau kontrol politik terhadap pesaing lainnya. Kemampuan koalisi partai politik dalam menjalin komunikasi terbuka dengan partai politik lainnya menjadi jembatan untuk menentukan pasangan yang akan 
maju dalam pilkada. Gambaran koalisi partai politik pendukung pasangan calon gubernur dan wakil gubernur Riau tahun 2018, Syamsuar dan Edy Natar Nasution, dapat dilihat pada Tabel 6 .

Tabel 6

Jumlah Kursi Partai Koalisi Pasangan Syamsuar-Edy Natar Nasution

\begin{tabular}{lc}
\hline \multicolumn{1}{c}{ Partai politik } & $\begin{array}{c}\text { Perolehan Kursi DPRD } \\
\text { RIAU 2014-2019 }\end{array}$ \\
\hline Partai Amanat Nasional (PAN) & 7 Kursi \\
\hline Partai Keadilan sejahtera (PKS) & 3 Kursi \\
\hline Partai Nasional Demokrat (Nasdem) & 3 Kursi \\
\hline Jumlah & 13 Kursi \\
\hline
\end{tabular}

Dalam proses penetapan calon, DPW PKS dan DPW PAN kemudian menetapkan Syamsuar sebagai calon gubernur yang diusungnya. Sedangkan untuk calon wakil gubernur, DPW PKS dan PAN mendapatkan dua kandidat calon wakil gubernur, yaitu Edy Natar Nasution, Danrem 031/Wirabima Pekanbaru, dan Ketua DPW Partai Nasdem Riau, Iskandar Housien. Tetapi, pada proses penetapan calon, akhirnya Iskandar Housien memberikan dukungan kepada Edy Natar Nasution. Dengan tidak adanya kader internal partai yang mengikuti proses pencalonan selanjutnya sebagai calon wakil gubernur, DPW Partai Nasdem Riau akhirnya merekomendasikan Edy Natar Nasution sebagai calon wakil gubernur yang akan mendampingi Syamsuar.

Pasangan Syamsuar dan Edy Natar Nasution merupakan pasangan calon gubernur dan wakil gubernur Riau yang berasal dari kader eksternal partai dan kader non-partai. Syamsuar adalah Ketua DPD II Partai Golkar Siak dan Edy Natar Nasution adalah Danrem 031/Wirabima Pekanbaru. Koalisi partai pengusung Syamsuar dan Edy Natar Nasution tergabung dalam Koalisi Riau Bersatu (KARIB) terdiri dari PKS, PAN dan Partai Nasdem.

Koalisi ini mengusung Pasangan Syamsuar dan Edy Natar Nasution dengan jargon "Membangun Riau Lebih Baik." Sedangkan visinya adalah "Terwujudnya Riau yang Berdaya Saing, Sejahtera, Bermartabat dan Unggul di Indonesia (Riau Bersatu)" (Media Indonesia.com 2018). Adapun misi pasangan calon Gubernur dan Wakil Gubernur Riau Syamsuar-Edy Natar Nasution adalah 1) mewujudkan sumber daya manusia yang beriman, berkualitas dan berdaya saing global melalui pembangunan manusia seutuhnya; 2) mewujudkan pembangunan infrastruktur daerah yang merata, berwawasan lingkungan dan berkelanjutan; 3) mewujudkan 
pembangunan ekonomi yang inklusif, mandiri dan berdaya saing; 4) mewujudkan budaya Melayu sebagai payung negeri dan mengembangkan pariwisata yang berdaya saing; dan 5) mewujudkan tata kelola pemerintahan yang baik dan pelayanan publik yang prima berbasis teknologi informasi.

Mengacu pada visi tersebut, program kerja yang dijanjikan oleh pasangan Syamsuar-Edy Nasution adalah 1) pendidikan yang berkualitas dengan cara meningkatkan kualitas guru, memberikan insentif guru dan juga memberikan beasiswa S1, S2 dan S3 dalam negeri dan luar negeri untuk guru \& anak Riau yang berprestasi dan tidak mampu; 2) pelayanan kesehatan lebih baik dengan cara meningkatkan pelayanan kesehatan, meningkatkan status Puskesmas di daerah terpencil atau sulit terjangkau menjadi rumah sakit pratama Tipe D dan menyiapkan sarana pengaduan BPJS; 3) pemerataan pembangunan dengan cara membangun dan memperbaiki jalan menuju kawasan strategis, membangun listrik pedesaan dan perkotaan, membangun rumah layak huni, meningkatkan infrastruktur dasar daerah terisolir dan daerah perbatasan, pemenuhan akses air bersih/minum bagi masyarakat, bantuan keuangan provinsi untuk desa dan kabupaten/kota, dan meningkatkan peran CSR dalam pembangunan serta mengembangkan kerjasama antar daerah; 4) peningkatan ekonomi kerakyatan dan penanggulangan kemiskinan dengan cara bantuan peremajaan kelapa sawit, kelapa dan karet, bantuan budidaya ikan tawar dan perikanan laut, bantuan permodalan ukm, bantuan untuk keluarga miskin, dan mengembangkan produk unggulan desa/kecamatan serta membangun Pasar Online Riau (Riau E-Commerce); 5) penyediaan lapangan kerja dengan cara pelatihan kewirausahaan bagi generasi muda, membangun wadah Ekonomi Kreatif Riau (Riau Creative HUB), dan mendirikan UPT BLK (Balai Latihan Kerja) serta mengembangkan kawasan Industri; 6) pembangunan keagamaan dengan cara membangun Quran Centre di Pekanbaru, pengelolaan zakat di kabupaten/ kota serta membina kerukunan umat beragama; 7) pembangunan pariwisata dan budaya dengan cara membangun desa wisata, menjadikan Riau sebagai destinasi wisata nasional, menyelenggarakan festival seni \& budaya bertaraf nasional \& internasional, dan mengembangkan wisata olahraga (sport tourism) bertaraf nasional dan internasional; dan 8) penyelanggaraan pemerintah yang baik dan bebas dari KKN dengan cara pelayanan terpadu satu pintu, menerapkan sistem perizinan online terintegrasi, pelayanan publik online menuju Riau Smart City, menandatangani pakta integritas anti $\mathrm{KKN}$, dan menyediakan sistem pengaduan masyarakat.

\section{Pemberdayaan Politik}

Salah satu misi PKS Riau adalah membangun kesadaran politik masyarakat dan melakukan pembelaan dan pemberdayaan hak-hak kewarganegaraan mereka. Terkait dengan upaya pemberdayaan dan pola pendidikan politik, diperlukan suatu pola pendidikan sosial politik. Visi umum PKS adalah menjadi "partai dakwah penegak keadilan dan kesejahteraan dalam bingkai persatuan umat dalam 
mewujudkan masyarakat Indonesia yang madani”. Sedangkan visi khusus PKS adalah menjadi "partai berpengaruh, baik secara kekuatan politik, partisipasi maupun opini dalam mewujudkan masyarakat Indonesia yang madani" (pks.id 2014).

Masyarakat madani dalam pengertian PKS adalah masyarakat berperadaban tinggi dan maju yang berbasiskan pada nilai-nilai, norma, hukum, moral yang ditopang oleh keimanan, menghormati pluralitas, bersikap terbuka, gotong royong, demokratis dan menjaga kedaulatan negara. Masyarakat madani ini dipadukan dengan konteks masyarakat Indonesia di masa kini yang terikat dalam ukhuwah Islamiyah (ikatan keislaman), ukhuwah wathaniyah (ikatan kebangsaan) dan ukhuwah basyariyah (ikatan kemanusiaan) dalam bingkai NKRI.

Dalam menjalankan roda organisasinya, PKS dibingkai oleh peraturanperaturan yang mengikat seluruh anggota partai. Roda organisasi dikendalikan oleh Dewan Pengurus Pusat (DPP) yang pengelolaanya direncanakan sedemikian rupa oleh tim pusat yang dipilih melalui seleksi dan musyawarah tertutup. Selain itu, struktur kepengurusan di wilayah regional disebut dengan Dewan Pengurus Wilayah (DPW) dan Dewan Pimpinan Daerah (DPD) yang mengelola wilayah setingkat provinsi dan kota/kabupaten.

Itulah dasar organisasi PKS yang secara internal-subjektif menghimpun kader-kadernya dalam barisan yang rapi untuk memperjuangkan aspirasi umat dan mencapai tujuan nasional. Atas dasar itu pula, PKS membangun etika politik khususnya bagi para kader dan bahkan militansi memperjuangkan para kader termasuk semangat rela berkorban. Mereka berkeyakinan bahwa aktivitas politik bukan hanya sekedar kegiatan profan-duniawi, tetapi sarat dengan dimensi sakralreligius ukhrawi yang bernilai ibadah. Aktivitas politik dapat menjadi ruang ekspresi dan menguak potensi diri dan juga sebagai tempat bagi kader untuk berkhidmat kepada publik sebagai bagian dari bentuk pengkhidmatan mereka terhadap agama yang sarat dengan aspek spiritual dan kemanusiaan. Bagi PKS, darah pergerakan itu menjadi mungkin dengan menempatkan Islam secara internal-subjektif sebagai akidah, asas (ideologi) dan moralitas perjuangan. Substansi moralitas perjuangan PKS sendiri adalah bersih, peduli dan profesional.

Keputusan DPP PKS mengusung Syamsuar merupakan kebijakan partai yang sudah melalui proses yang cukup panjang. Meskipun, pada saat pemilihan presiden dan wakil presiden tuntuk periode jabatan 2019-2024, publik Riau sempat dikagetkan oleh Syamsuar yang menjadi salah satu kepala daerah yang terang-terangan mendeklarasikan Joko Widodo sebagai calon presiden (kompas. com 2018). Hal tersebut bertentangan dengan arah dukungan PKS secara nasional yang mendukung Prabowo Subianto sebagai calon presiden. Dalam berpolitik terkadang ada hal-hal di luar prediksi yang terjadi dan partai maupun individu harus siap menyikapinya secara dinamis.

Siapapun figur yang sudah diputuskan oleh DPP PKS berarti diyakini sudah melalui proses pengambilan keputusan yang matang dan harus diperjuangkan 
secara militan oleh seluruh komponen internal PKS untuk mencapai tujuan tersebut. Sebagai pemberdayaan politik, kader partai tetap menjunjung tinggi visi misi, AD ART, dan etika politik yang kuat. Karena itu, dukungan kader sama kuatnya dengan komitmen partai ketika memutuskan mencalonkan Syamsuar-Edy Natar Nasution pada pemilihan gubernur dan wakil gubernur tahun 2018. Seluruh stakeholder PKS dan simpatisan memiliki komitmen mendukung penuh agenda kebijakan partai politik dalam rangka mewujudkan sistem pemerintahan yang madani dan sejahtera lahir dan batin.

\section{Komunikasi Politik}

Untuk memenangkan pemilihan, kandidat membentuk suatu strategi komunikasi yang menampilkan pesan-pesan politik melalui isu, tema dan slogan di berbagai media seperti televisi, radio dan internet. Hal ini diharapkan dapat memelihara momentum yang secara efektif dapat mencapai target kelompok tertentu. Diperlukan strategi komunikasi kandidat untuk mencapai target khalayak tertentu yang berpengaruh, baik pemilih mengambang atau pemilih pemula maupun pemilih umum lainnya. Media menjadi salah satu sarana efektif dalam menyampaikan pesan pada khalayak ramai. Pemilihan media dipengaruhi oleh khalayak sasaran yang akan dituju, efek yang diharapkan dari program komunikasi yang dijalankan dan isi pesan yang dikomunikasikan. Media massa dipilih dalam mengimplementasikan strategi pencitraan kandidat, baik melaui media cetak, media eletronik maupun media internet.

Strategi komunikasi politik yang dilakukan PKS yang tergabung dalam koalisi pemenangan Koalisi Riau Bersatu (KARIB) adalah menggunakan media massa untuk mempromosikan pasangan Syamsuar-Edy Natar Nasution. Media cetak yang dipilih adalah Riau Pos dan Tribun Pekanbaru. Kemudian digunakan pula media berskala kecil seperti selebaran, spanduk, poster, stiker, majalah dinding dan papan nama untuk memasang tanda gambar kandidat. Juga menggunakan media sosial seperti Facebook, Instagram dan Twitter untuk mengkampanyekan pasangan ini secara masif. PKS Riau memiliki juga website resmi yang cukup lengkap tidak hanya di di tingkat DPW, tetapi Juga di tingkat DPD kabupaten/ kota di Riau. Dengan website tersebut, PKS dapat dengan mudah mempromosikan kandidatnya pada saat Pilkada dilaksanakan.

Dengan menggunakan berbagai saluran media tersebut, PKS bersama partai koalisi mengoptimalisasikan strategi kampanye dan propaganda politiknya. Dengan memanfaatkan berbagai media pendukung dengan cepat menyebarluaskan figur kandidat kepada khalayak. Komunikasi politik merupakan bagian dalam komunikasi di organisasi politik. Hal ini dapat dilihat dari pola komunikasi dalam komunikasi politik yang juga terdapat dalam komunikasi organisasi seperti komunikasi internal, eksternal, vertikal, horizontal, satu arah, dua arah, verbal, dan nonverbal. 
Komunikasi politik yang berlangsung dalam strategi politik terbuka PKS Riau melibatkan komunikator-komunikator politik dari PKS dan dari luar PKS. Komunikasi juga melibatkan kader, simpatisan, masyarakat Riau, dan tamu undangan sebagai komunikannya. Komunikasi politik yang terjadi dalam keterbukaan ideologi melalui pesan verbal dan nonverbal disampaikan dalam beberapa kegiatan DPW PKS Riau seperti Muswil, Rakerwil dan Rakorwil dalam agenda pokok partai dan pemenangan kandidat yang diusung partai pada Pilkada Riau 2018.

Komunikasi politik dalam keterbukaan ideologi DPW PKS Riau terjadi melalui pola komunikasi organisasi karena aktivitas komunikasi dilakukan oleh organisasi politik/partai politik. Komunikasi melalui kegiatan tersebut dilakukan oleh berberapa komunikator politik dari internal dan eksternal PKS, dengan komunikan juga dari internal dan eksternal. Komunikator memberikan pesan dalam bentuk pidato dan arahan. Hal ini dilakukan dengan pemahaman mengenai keterbukaan ideologi melalui pesan-pesan politik yang disampaikan dan diusung oleh PKS. Kemudian, secara simbolis DPW PKS Riau juga menunjukkan keterbukaan ideologi dalam bentuk simbol-simbol nonverbal seperti undangan kepada partai lain dan ormas Islam, pelestarian seni dan budaya daerah, dan kegiatan kemasyarakatan sehingga terbangun citra partai yang inklusif dan berkhidmad untuk rakyat.

Secara lebih luas, uraian di atas juga menunjukkan bahwa dinamika politik dan pemerintahan lokal yang berjalan dalam pilkada memperlihatkan sejauhmana demokratisasi di tingkat lokal terimplementasikan dengan baik, tak hanya terkait dengan tingkat partisipasi, tetapi juga relasi kuasa yang dibangun yang bersumber dari pelaksanaan azas kedaulatan rakyat. Meskipun PKS awalnya merupakan partai Islamis yang cenderung tertutup, pragmatisme politik menggeser partai ini semakin ke tengah untuk mendapatkan dukungan pemilih yang lebih besar dengan tetap taat pada aturan main dalam sistem demokrasi. Selain itu, dinamika partai tersebut juga terkait dengan hasil pilkada yang diharapkan untuk menghantarkan masyarakat kepada kondisi sosial, politik dan ekonomi yang lebih baik. Tentunya, esensi dari semua proses tersebut adalah terwujudnya tatanan pemerintahan yang baik (good governance). Tata pemerintahan adalah penggunaan wewenang ekonomi, politik dan administrasi guna mengelola urusan-urusan negara pada semua tingkat. Tata pemerintahan mencakup seluruh mekanisme, proses dan lembaga-lembaga di mana warga dan kelompok-kelompok masyarakat mengutarakan kepentingan mereka, menggunakan hak hukum, memenuhi kewajiban, dan menjembatani perbedaan-perbedaan di antara mereka (Syamsuadi 2018).

\section{Kesimpulan}

Artikel ini telah menunjukkan bahwa PKS sebagai partai dakwah telah mengadopsi pragamatisme politik untuk memenangkan persaingan meraih suara rakyat dengan melakukan sejumlah strategi politik terbuka, yaitu mobilisasi massa, optimalisasi 
koalisi partai terbuka, pemberdayaan politik dan strategi komunikasi politik. Hal ini terlihat jelas dalam strategi politik PKS pada Pemilihan Kepala Daerah Riau tahun 2018. Dalam upaya melakukan strategi koalisi partai secara terbuka, PKS melakukan konsolidasi lebih intens dan membangun soliditas dengan berbagai pihak terutama sayap partai bersama partai koalisi pengusung dari kalangan partai nasionalis untuk bekerja dan bergerak bersama-sama dalam melakukan marketing politik. Hal ini kemudian juga diperkuat melalui optimalisasi berbagai media sebagai bagian dari komunikasi politik dalam mendukung kandidat yang diusungnya pada pemilihan gubernur dan wakil gubernur Riau tahun 2018.

Kajian ini menegaskan bahwa PKS menyadari bahwa untuk memenangkan persaingan politik tersebut, strategi politik terbuka dalam sistem politik demokrasi di Indonesia menjadi prasyarat penting dalam membangun pragmatisme politiknya. Karena itu, anggapan bahwa PKS yang menganut ideologi Islam politik yang tertutup dan hanya menunggangi sistem demokrasi adalah kurang tepat. Sebagai partai Islam terbesar di Indonesia, PKS berhasil membuktikan bahwa pragmatisme politik melalui strategi politik terbuka menjadi kunci penopang utama keberhasilannya dalam persaingan politik di Indonesia.

\section{Referensi}

“Anggaran Rumah Tangga Partai Keadilan Sejahtera'. Diunduh dari (http://pks.id/ file/ad-art-pksAnggaran Dasar)

Akbar, Idil. 2017. "Pilkada Serentak dan Geliat Dinamika Politik dan Pemerintahan Lokal Indonesia." CosmoGov 2(1): 95-110.

"Amien Rais hadiri deklarasi Syamsuar-Edy Nasution di Riau". Diunduh dari (https://news.detik.com/berita/d-3803083/amien-rais-hadiri-deklarasisyamsuar-edy-nasution-di-riau)

Anggito, Albi dan Johan Setiawan. 2018. Metodologi Penelitian Kualitatif. Sukabumi: CV Jejak.

Budiardjo, Miriam. 2008. Dasar-Dasar Ilmu Politik. Edisi Revisi. Jakarta: Gramedia.

Damanik, Ali Said. 2002. Fenomena Partai Keadilan: Transformasi 20 Tahun Gerakan Tarbiyah di Indonesia. Jakarta: Teraju.

"Diusung PKS dan PAN, Gubernur Riau Syamsuar Dukung Jokowi”. Diunduh dari https://nasional.kompas.com/read/2019/02/20/11250611/diusung-pksdan-pan-gubernur-riau-syamsuar-dukung-jokowi.

Fuad, Ai Fatimah Nur. 2017. "Islamism and Dakwah in Late Modern Indonesia: Official Discourses and Lived Experiences of Leaders and Members of the Tarbiyah Movement," Disertasi. University of Leeds.

Hasan, Noorhaidi. 2012. "Islamist Party, Electoral Politics and Da'wah Mobilization among Youth: The Prosperous Justice Party (PKS) in Indonesia." Journal of Indonesian Islam, 6 (1):17-47. 
Hassan, Sahar L, Kuat Sukardiyono, dan Dadi M. H. Basri. 1998. Memilih Partai Islam: Visi, Misi dan Persepsi. Jakarta: Gema Insan.

Hidayat, Syahrul. 2012. "Managing Moderation: The AKP in Turkey and the PKS in Indonesia" $\mathrm{PhD}$ thesis. University of Exeter.

Hilmy, Masdar. 2010. Islamism and Democracy in Indonesia: Piety and Pragmatism. Singapore: ISEAS.

“Koalisi Riau Bersatu Deklarasikan Syamsuar-Edy di Pilgub Riau 2018”. Diunduh dari (https://mediaindonesia.com/read/detail/139699-koalisi-riau-bersatudeklarasikan-syamsuar-edy-di-pilgub-riau-2018)

Machmudi, Yon. 2006. "Islamizing Indonesia: the Rise of Jamaah Tarbiyah and the Prosperous Justice Party”. Disertasi. The Australian National University.

Muhtadi, Burhanudin. 2012. Dilema PKS: Suara dan Syariah. Jakarta: KPGGramedia.

Nurdin, Ahmad Ali. 2009. "Islamic Political Parties and Democracy: A Comparative Study of PKS in Indonesia and PAS in Malaysia (1998-2005)". Disertasi. National University of Singapore.

Nurdin. Ahmad Ali. 2019. "The Influence of Middle Eastern Islamic Political Thought on Islamic Political Parties in Indonesia: The Case of PKS" GJAT 9 (3): 27-37.

Permata, Ahmad Norma. 2008. "Islamic Party and Democratic Participation: the Prosperous Justice Party (PKS) in 1998-2006". Disertasi. University of Munster.

Permata, Ahmad Norma. 2013. "A Study on the Internal Dynamics of the Justice and Welfare Party (PKS) and Jama'ah Tarbiyah”. Pp. 241-294 in Regime Change, Democracy, and Islam: the Case of Indonesia. Leiden: Universiteit Leiden.

“Perolehan Suara Pilkada Riau 2018”. Diunduh dari (https://riau.kpu.go.id/web/ perolehan-suara/)

Rahmat, Imdadun. 2008. Ideologi Politik PKS: dari Masjid Kampus ke Gedung Parlemen. Yogyakarta: LKiS.

Romadan, Ahmad. 2019. "Dinamika Kandidasi Partai Politik pada Pemilihan Kepala Daerah di Provinsi Riau Tahun 2017-2018." Jurnal Online Mahasiswa Bidang Ilmu Sosial dan Ilmu Politik 6(1):1-15.

Sahid, Asep Abdul dan Kadar Nurjaman. 2017. "Literasi Politik Masyarakat Pesisir dan Manajemen Partai Politik.” JISPO Jurnal Ilmu Sosial dan Ilmu Politik 7(2): 137-57.

Syamsuadi, Amir. 2018. "Membangun Demokrasi Pemerintahan di Riau Dalam Perspektif Budaya Melayu.” Jurnal Dinamika Pemerintahan 1(1):1-10.

Syamsuadi, Amir, dan M. H. D. Rafi Yahya. 2018. "Model Kandidasi Birokrat oleh Partai Politik pada Pemilihan Kepala Daerah Langsung di Kabupaten Rokan Hilir Tahun 2015." Journal of Governance 3(2): 133-53. 
"Sosial-Budaya". Diunduh dari (https://www.riau.go.id/home/content/67/sosialbudaya)

Tawakkal, George Towar Ikbal. 2009. "Peran Partai Politik dalam Mobilisasi Pemilih: Studi Kegagalan Parpol pada Pemilu Legislatif di Kabupaten Demak 2009." Tesis. Universitas Diponegoro.

Wijaya, Sri Herwindya Baskara. 2014. "Komunikasi Politik Partai Terbuka ala PKS.” Naskah Publikasi Universitas Sebelas Maret. 
